\title{
Experiences of Caregiving, Satisfaction of Life, and Social Repercussions Among Family Caregivers, Two Years Post-Stroke
}

\author{
KÀTIA LURBE-PUERTO, PhD \\ INtegrative research unit on Social and Individual DEvelopment (INSIDE), \\ Walferdange, Luxembourg \\ MARIA-ENGRACIA LEANDRO, PhD \\ Research Centre in Sociology, ISCTE/University Institute of Lisbon, Braga, Portugal \\ and Faculty of Social Sciences, Catholic University of Braga, Braga, Portugal \\ MICHÈLE BAUMANN, PhD \\ INtegrative research unit on Social and Individual DEvelopment (INSIDE), \\ Walferdange, Luxembourg
}

Cerebrovascular diseases are a public health and social policy priority in Europe due to their high prevalence and the long-term disability they may result in (as the principal cause of handicap). Increasingly, family caregivers take over the care at home of these patients. Two years post-stroke, our study analyzed the feelings of family caregivers from Luxembourg and northeastern Portugal toward their experience of caregiving and its repercussions on social and couple relationships, life satisfaction, and socioeconomic characteristics. Participating hospitals identified survivors and consent was sought by letter. Patients $(\mathrm{n}=62)$ and their main caregivers ( $\mathrm{n}=46$ pairs) were interviewed at home. The mean life satisfaction of caregivers was similar, but the

Received August 30, 2011; accepted April 26, 2012.

Thanks to Etienne Le Bihan (University of Luxembourg, Research Unit INSIDE) who conducted the statistical analyses and Marie-José Gomes (University of Minho, Department of Sociology, Portugal) who organized the survey in the North-eastern of Portugal. The project "Living in the Grand-Duchy of Luxembourg after a stroke: family repercussions and quality of life. Equality of access to healthcare and social resources" was financed by the National Fund for Research, Luxembourg FNR/VIVRE 06/06/06, the University of Luxembourg, and the Research Centre for Health.

Address correspondence to Prof. Michèle Baumann, University of Luxembourg, Research Unit INSIDE, B.P. 2, L-7201 Walferdange, Luxembourg. E-mail: michele.baumann@uni.lu 
experience of providing care differed in terms of family support, and disruptions of the caregivers' family responsibilities. More Portuguese respondents gave activities up, found little time for relaxation, and estimated that their health had deteriorated; more Luxembourgers felt strong enough to cope. More Portuguese spouses reported an impact on their sex lives. Family caregivers represent a "population at risk." Social workers can help them by providing domestic assistance, undertaking coaching activities, fostering favorable attitudes, and offering reassurance. Home-based rebabilitation in Europe involving family care must take account of cultural lifestyle issues.

KEYWORDS experiences of caregiving, family caregiver, care provision setting

\section{INTRODUCTION}

Cerebrovascular diseases are an important public health and social policy concern (OMS Europe, 2004), due not only to their high prevalence, but also to the long-term disability they cause (Wolfe, 2000) and the substantial social, economic, and emotional impact they have on the daily lives of the people affected (Han \& Haley, 1999). Because of the personal challenges stroke poses to the everyday lives of patients (Han \& Haley, 1999; Rosamond et al., 2007), it is considered a "critical life event" (Miller, 1989). The upheavals stroke involves for the close relatives mean it is also a family issue (Ostwald, 2004).

One year after the stroke event, the affected family members start to find new ways of resolving family problems, of communicating and of dealing emotionally with each other, and they redefine their roles accordingly (Clark \& Smith, 1999). By that time, family caregivers (spouse, son/daughter) have accumulated considerable experience with health care tasks and carrying out the caregiving role (Baumann, Lurbe-Puerto, Alzahouri, \& Aïach, 2011). Moreover, the relocation of long-term care to the home has brought them new responsibilities, and they have gained experience in relating to professionals, institutions, associations, and their care-recipients (Wiles, 2003). Some studies (Poulshock \& Deimling, 1984; Given, Stommel, Collins, King, \& Given, 1992; Nijboer, Triemstra, Tempelaar, Sandermanc, \& Van Den Bosa, 1999; Antoine, Quandalle, \& Christophe, 2010) have incorporated in their instruments both burdensome experiences and commitments and normative responsibilities toward the care-recipient. In this period, patients and their family caregivers value attention being given to their own thoughts and home situation by the health professionals and social workers involved (Salisbury, Wilkie, Bulley, \& Shiels, 2010).

The central role of family caregivers in community-based rehabilitation is widely recognized (Baumann, Briançon, \& Deschamps, 1992). People 
who suffer stroke of moderate severity and who benefit from a high level of social support recover from most of their physical and cognitive impairments (Tsouna-Hadjis, Vemmos, Zakopoulos, \& Stamatelopoulos, 2000; Gottlieb, Golander, Bar-Tal, \& Gottlieb, 2001). Some studies have observed that the family caregivers of stroke patients who have lower life satisfaction have lower health-related quality of life, a greater prevalence of stress and depression, more economic burden, and an impoverished social life (Brännholm, Lundmark, Mansson, \& Fugl-Meyer, 1996; Vitanen, Fugl-Meyer, Bernspang, \& Fugl-Meyer, 1988). Life satisfaction has been considered as an outcome of the quality of life; it is of interest as it reflects the cognitive connection between an individual's aspirations, achievement, and contentment (Musschenga, 1997). It does not necessarily refer to fulfilment in all aspects of life (Campbell, 1981) and may differ from objective appraisals made by others (Veenhoven, 2000). Recently, the Eurofund introduced a life satisfaction indicator into the European Quality of Life Surveys of 2007 and 2009 to reflect genuine population concerns (EFILWC, 2009, 2010); we also opted to include it in our analyses.

A recent research program looking at continuity of care for chronically ill people (Parker, Corden, \& Heaton, 2011) showed that caregivers seek recognition of their role and their contribution to care. From their point of view, this recognition would encourage professionals to provide timely and correct information to help them facilitate practical care (giving medication and arranging appointments). Family caregivers also want acknowledgment of their own need for support and responsive help, including in dealing with their emotional responses to diagnoses, delays in service delivery and the impact of the illness on the person they are caring for.

Interventions to improve community-based rehabilitation should be designed on the basis of sound information (Oupra, Griffiths, Pryor, \& Mott, 2010). The post-stroke period comprises three distinct phases as regards the treatment and the type of support required by patients: the acute phase, the rehabilitation phase, and the chronic phase. Neurological recovery and functions may continue to improve for up to a further 18 months (National Stroke Association, 2007). Two years post-stroke seems an appropriate time to appraise the extent to which the stroke onset has affected individual reactions and family plans for the future, but there are differences between the lifestyles of family caregivers. In Portugal they are more reliant on family support (Leandro, 2009; Leandro, Baumann, \& Felizes, 2011). Our hypotheses are that differences can be observed between southern and northern Europe in the experience of caregiving, the repercussions on social relationships, and life satisfaction. This research contributes to the identification of the sociocultural determinants, 2 years post-event, which have an impact in these different socioeconomic situations.

Awareness of the relevance of the social and financial conditions in which the caregiving role is carried out (Mold, McKevitt, \& Wolfe, 2003), 
and of inequalities in the resources available for home-caregiving, led us to launch two surveys with the same protocol. The first was organized in Luxembourg, where stroke is the principal cause of acquired handicap and the third leading cause of death (Eurostats, 2009). For the second survey, we collaborated with a university team in northeast Portugal because the southern European countries are known to have low cardiovascular mortality and high life expectancy, with the exception of Portugal, where stroke is the principal cause of both handicap and death (Eurostats, 2009). By focusing on the chronic post-stroke phase, our aim was to analyse the reactions of family caregivers from Luxembourg and from north-eastern Portugal, toward their experiences of caregiving, its repercussions on social and couple relationships, life satisfaction, and socioeconomic characteristics.

We intended to identify the specificities of Luxembourg as regards another European country; namely, Portugal and in particular, its northeast region. As more than 33\% of the Luxemburg population descents from immigrants coming from Portugal, we presumed that common lifestyles would be brought to light.

\section{METHODS}

\section{Survey Samples}

We decided to focus our study on the whole population of stroke survivors admitted to all hospitals between July 1, 2006 and June 30, 2007. In order to fulfil this inclusion criterion, the survey took place in Luxembourg and northeastern Portugal from March 1, 2008 to February 28, 2010.

Those patients ( $n=374$ and 132, respectively) living at home 2 years after the event were identified and sent a letter explaining the aims of the survey and inviting them to participate. They were asked to send back their written informed consent and to indicate "the person who mostly takes care of me since the stroke event," here considered as the main caregiver. After receiving each patient's signed informed consent, the research teams telephoned (up to five attempts) to make an appointment. Patients and their main caregiver were visited, and the caregiver's consent was obtained.

\section{Procedures}

Two researchers, one per interview, conducted the face-to-face structured interviews supported by a questionnaire.

The data collected among the patients included:

- Sociodemographic characteristics: age; sex; educational level (under 12th grade; 12th grade and above); occupation at the time of the stroke event (never employed; manual worker; employee + intermediate professional/technician; farmer; manager + liberal professional) 
- Neurological impairments and residual disabilities at the time of the survey were documented for six functions (motor, sensory, vision, affect, cognition, and language) as formulated by the American Heart Association Stroke Outcome Classification (AHA.SOC) (Kelly-Hayes et al., 1998)

- Life satisfaction: a simple measure was used to provide a subjective appraisal by asking respondents to self-rate their life satisfaction on a 10point scale: "On a scale from 1 to 10, where would you place your level of satisfaction with your life?" (10 being the highest level) (EFILWC, 2009, 2010)

The data collected among the family caregivers were:

- Sociodemographic characteristics and life satisfaction, as for patients with the addition of the relationship with the stroke survivor (spouse, son/daughter, other).

- Social and family repercussions (see Table 2), as drawn from a previous qualitative study (Baumann \& Aïach, 2009), we assessed the impact on nuclear family relationships, material repercussions, changes in the roles of family members; changes in the attitudes of relatives and friends toward the stroke-affected person and the psychological repercussions for caregivers.

- Experience of caregiving (see Table 3) using the items of the Caregiver's Reaction Assessment instrument (Given et al., 1992 for the English version; Antoine et al., 2010 for the French version), which explores self-esteem, family support (or lack of it), financial problems, the impact of caregiving on scheduled activities, and health problems.

- Spouses of care-recipients were specifically asked about stroke-related repercussions on the couple relationship (see Table 4), which covered disruptions within the couple relationship, and changes in the distribution of roles within the couple.

Possible responses to each item were: completely agree, agree, disagree, and completely disagree.

As Luxembourg is a multilingual country, our questionnaires were available in four languages: Luxembourgish, Portuguese, French, and German. Most of the instruments were already available in French or English. The German, Portuguese, and Luxembourgish versions were translated and back-translated, and proofread by native-speaking professional translators.

\section{Statistical Data}

As regards the analysis of our data, quantitative continuous variables were compared using Student's test or the Mann-Whitney test, and categorical variables were compared using the $\mathrm{Chi}^{2}$ test or Fisher's exact test; significance 
level $p \leq .05 ; p \leq .01 ; p \leq .001$. Percentages indicate the proportions of respondents who "completely agree" or "agree."

\section{RESULTS}

Sixty-two patients and 46 patient/main caregiver pairs from Luxembourg and northeastern Portugal are included in the statistical analyses.

Sociodemographic and stroke-related characteristics are shown in Table 1.

Patients were mainly men. Mean age of Luxembourg respondents was 64.4 years, making them an average of 6 years younger than their Portuguese counterparts (70.6 years). Self-assessed levels of life satisfaction

TABLE 1 Socioeconomic and Stroke-Related Characteristics, Life Satisfaction. Mean (SD) or \%

\begin{tabular}{|c|c|c|c|c|c|c|}
\hline & $\begin{array}{c}\text { Luxembourg } \\
\text { patients } \\
n=62\end{array}$ & $\begin{array}{l}\text { Portugal } \\
\text { patients } \\
n=46\end{array}$ & $p$ & $\begin{array}{c}\text { Luxembourg } \\
\text { caregivers } \\
n=62\end{array}$ & $\begin{array}{c}\text { Portugal } \\
\text { caregivers } \\
n=46\end{array}$ & $p$ \\
\hline Age & $64.4(15.8)$ & $70.6(9.7)$ & $\leq .05$ & $59.3(13.7)$ & $60.7(13.0)$ & .592 \\
\hline \multicolumn{7}{|l|}{ Sex } \\
\hline Women & 40.3 & 41.3 & \multirow[t]{2}{*}{1.000} & 65.5 & 82.6 & \multirow[t]{2}{*}{.078} \\
\hline Men & 59.7 & 58.7 & & 34.5 & 17.4 & \\
\hline \multicolumn{7}{|l|}{ Educational level } \\
\hline Under 12 th grade & 44.4 & 89.1 & \multirow{2}{*}{$\leq .001$} & 42.4 & 76.1 & \multirow{2}{*}{$\leq .001$} \\
\hline $\begin{array}{l}\text { 12th grade and } \\
\text { above }\end{array}$ & 55.6 & 10.9 & & 57.6 & 23.9 & \\
\hline \multicolumn{7}{|l|}{ Occupation } \\
\hline Never employed & 20.4 & 30.4 & \multirow{4}{*}{$\leq .01$} & 17.5 & 37.0 & \multirow[t]{4}{*}{$\leq .05$} \\
\hline Manual worker & 22.2 & 15.2 & & 14.0 & 17.4 & \\
\hline Farmer & 3.7 & 26.1 & & 3.5 & 4.3 & \\
\hline $\begin{array}{l}\text { Employee, } \\
\text { technician or } \\
\text { intermediate } \\
\text { professional }\end{array}$ & 35.2 & 15.2 & & 49.1 & 17.4 & \\
\hline $\begin{array}{l}\text { Manager + Liberal } \\
\text { Profession }\end{array}$ & 18.5 & 13.0 & & 15.8 & 23.9 & \\
\hline \multicolumn{7}{|l|}{ Relationship with } \\
\hline $\begin{array}{l}\text { the care-recipient } \\
\text { Spouse }\end{array}$ & & & & 82.3 & 60.9 & \multirow[t]{3}{*}{$\leq .05$} \\
\hline Son/daughter & & & & 9.7 & 23.9 & \\
\hline Other & & & & 8.0 & 15.2 & \\
\hline \multicolumn{7}{|l|}{ Neurological } \\
\hline $\begin{array}{l}\text { impairments at the } \\
\text { visual functions }\end{array}$ & 22.6 & 13.0 & 316 & & & \\
\hline time of survey & 22.0 & 15.0 & & & & \\
\hline sensory functions & 53.2 & 45.7 & .560 & & & \\
\hline language functions & 35.5 & 45.7 & .324 & & & \\
\hline memory functions & 38.7 & 37.0 & 1.000 & & & \\
\hline Life satisfaction $[1 ; 10]$ & $7.1(1.6)$ & $5.7(2.0)$ & $\leq .001$ & $7.2(1.7)$ & $6.7(1.6)$ & .092 \\
\hline
\end{tabular}


were $7.1 / 10$ and 5.7/10, respectively. At the time of the stroke event, the majority of Luxembourg respondents were educated to the 12th grade or beyond, and the largest group of northeastern Portuguese were never employed or farmers (26.1\%).

Family caregivers were mainly women, with more spouses in Luxembourg and more daughters or sons in Portugal. More Luxembourg caregivers were educated to 12th grade or above, and had an occupation (employee, technician, or intermediate professional).

Stroke-related repercussions on social and family lives are presented in Table 2.

More Portuguese respondents reported effects on the nuclear family relationships and stroke-related financial and disruptions in the distribution of family responsibilities. They found such disruptions difficult to cope with, and said that since the stroke-onset they had to deal more often with professionals and handle household and administrative affairs. More recognized some changes in attitude toward the stroke-affected person. Even if the stroke-affected person had returned to his/her job position, he/she tended to be socially undervalued at work, and they revealed the psychological repercussions of that; all Portuguese agreed: "I did not know I had such inner resources."

Reactions to the experience of caregiving are described in Table 3.

More Portuguese estimated some disruption to the caregiver's activities, had given up activities, and said they could hardly find time for relaxation because of the constant interruptions that their role entailed. With regard to the impact on health, more Luxembourg respondents felt strong enough to care, whereas the health of Portuguese family caregivers had deteriorated.

Stroke-related repercussions on couples' lives are presented in Table 4.

Some disruptions within the couple relationship exist, but the greatest difference between the spouse respondents, especially for the Portuguese caregivers, is in: "In relation to sexuality, things have changed for us."

\section{DISCUSSION}

Our research contributes to the understanding of the divergences, 2 years post-event, of the experience of caregiving and its impact on social relationships among family caregivers from two different economic life conditions. Some of our results may be attributable to the contributions of social, financial, and cultural determinants. Our main findings showed that home-caregiving was experienced as less of a burden, and the strokerelated repercussions for the caregiver's family and social life were less disruptive among respondents living in Luxembourg. The primary question for the future is: How can physical and psychological exhaustion of family caregivers be prevented? This research focused on various facets of the 
TABLE 2 Stroke-Related Repercussions on Social and Family Lives. \% ${ }^{1}$

\begin{tabular}{|c|c|c|c|c|}
\hline & & $\begin{array}{l}\text { Luxembourg } \\
\text { caregivers } \\
n=62\end{array}$ & $\begin{array}{l}\text { Portugal } \\
\text { caregivers } \\
n=46\end{array}$ & $p$ \\
\hline \multirow{4}{*}{$\begin{array}{l}\text { Effects on the } \\
\text { nuclear family } \\
\text { relationships }\end{array}$} & $\begin{array}{l}\text { The stroke has brought serious } \\
\text { upheaval to my family. }\end{array}$ & 66.1 & 71.1 & .676 \\
\hline & $\begin{array}{l}\text { Stroke often puts a distance between } \\
\text { our children and us. }\end{array}$ & 10.5 & 0.0 & $\leq .05$ \\
\hline & $\begin{array}{l}\text { Some time after the stroke event, the } \\
\text { family worked together in taking } \\
\text { care of the stroke-affected person. }\end{array}$ & 78.0 & 93.5 & $\leq .05$ \\
\hline & $\begin{array}{l}\text { The stroke has strengthened family } \\
\text { bonds. }\end{array}$ & 69.0 & 87.0 & $\leq .05$ \\
\hline \multirow[t]{4}{*}{$\begin{array}{l}\text { Stroke-related } \\
\text { material } \\
\text { repercussions }\end{array}$} & $\begin{array}{l}\text { The stroke onset generally entails } \\
\text { moving to another house either for } \\
\text { more space or less. }\end{array}$ & 11.3 & 15.2 & .574 \\
\hline & $\begin{array}{l}\text { The stroke onset had financial } \\
\text { repercussions for the whole } \\
\text { household. }\end{array}$ & 27.4 & 54.3 & $\leq .01$ \\
\hline & $\begin{array}{l}\text { We have had to make some } \\
\text { rearrangements within the apartment } \\
\text { or house since the stroke onset. }\end{array}$ & 19.4 & 32.6 & .124 \\
\hline & $\begin{array}{l}\text { We have had to move into another } \\
\text { house because of the stroke event. }\end{array}$ & 8.3 & 6.7 & 1.000 \\
\hline \multirow{10}{*}{$\begin{array}{l}\text { Disruptions in } \\
\text { the distribution } \\
\text { of family } \\
\text { responsibilities }\end{array}$} & $\begin{array}{l}\text { Since the stroke event, I am more in } \\
\text { charge of the housekeeping, cooking } \\
\text { and shopping. }\end{array}$ & 13.2 & 40.0 & $\leq .01$ \\
\hline & $\begin{array}{l}\text { Since the stroke event, I more often } \\
\text { take care of administrative affairs. }\end{array}$ & 14.8 & 61.5 & $\leq .001$ \\
\hline & $\begin{array}{l}\text { I organize the holidays and the leisure } \\
\text { time more often than before the } \\
\text { stroke event. }\end{array}$ & 6.1 & 5.9 & 1.000 \\
\hline & $\begin{array}{l}\text { Since the stroke event, I am more in } \\
\text { charge of inviting friends and/or } \\
\text { relatives. }\end{array}$ & 5.7 & 0.0 & .548 \\
\hline & $\begin{array}{l}\text { Since the stroke event, I am more in } \\
\text { charge of driving the car. }\end{array}$ & 14.3 & 11.8 & 1.000 \\
\hline & $\begin{array}{l}\text { Since the stroke event, I am more in } \\
\text { charge of relationships with } \\
\text { professionals (health professionals, } \\
\text { cleaning professionals ...). }\end{array}$ & 34.1 & 75.0 & $\leq 0.001$ \\
\hline & $\begin{array}{l}\text { I have more household responsibilities } \\
\text { than before the stroke event. }\end{array}$ & 24.4 & 70.0 & $\leq .001$ \\
\hline & $\begin{array}{l}\text { The responsibilities are shared as } \\
\text { before. }\end{array}$ & 81.5 & 46.4 & $\leq .01$ \\
\hline & $\begin{array}{l}\text { I have found the changes in } \\
\text { responsibilities very difficult. }\end{array}$ & 11.4 & 78.6 & $\leq .001$ \\
\hline & $\begin{array}{l}\text { I cannot leave the stroke-affected } \\
\text { person alone for too long. }\end{array}$ & 36.1 & 78.3 & $\leq .001$ \\
\hline $\begin{array}{l}\text { Changes in } \\
\text { attitude } \\
\text { towards the } \\
\text { stroke-affected } \\
\text { person }\end{array}$ & $\begin{array}{l}\text { At the beginning nobody knew what } \\
\text { attitude to have with the } \\
\text { stroke-affected person. } \\
\text { Friends feel hampered, as they fear the } \\
\text { disability. }\end{array}$ & $\begin{array}{l}43.5 \\
6.8\end{array}$ & $\begin{array}{c}73.9 \\
8.9\end{array}$ & $\begin{array}{l}\leq .01 \\
.724\end{array}$ \\
\hline
\end{tabular}


TABLE 2 (Continued)

\begin{tabular}{|c|c|c|c|c|}
\hline & & $\begin{array}{l}\text { Luxembourg } \\
\text { caregivers } \\
n=62\end{array}$ & $\begin{array}{l}\text { Portugal } \\
\text { caregivers } \\
n=46\end{array}$ & $p$ \\
\hline \multirow{6}{*}{$\begin{array}{l}\text { Psychological } \\
\text { repercussions }\end{array}$} & $\begin{array}{l}\text { Even if the stroke-affected person has } \\
\text { come back to his/her work, he/she } \\
\text { is undervalued. }\end{array}$ & 26.4 & 71.7 & $\leq .001$ \\
\hline & $\begin{array}{l}\text { We received many expressions of } \\
\text { sympathy. }\end{array}$ & 76.7 & 100.0 & $\leq .001$ \\
\hline & $\begin{array}{l}\text { I did not know I had such inner } \\
\text { resources. }\end{array}$ & 77.0 & 100.0 & $\leq .001$ \\
\hline & $\begin{array}{l}\text { The stroke has been a painful event } \\
\text { requiring lots of effort and love to } \\
\text { overcome it. }\end{array}$ & 78.0 & 71.4 & .578 \\
\hline & $\begin{array}{l}\text { The psychological side of the stroke } \\
\text { has been the most difficult to face. }\end{array}$ & 70.5 & 91.3 & $\leq .01$ \\
\hline & $\begin{array}{l}\text { Caregiver's self-rated level of happiness } \\
\text { is very high. }\end{array}$ & 28.3 & 8.7 & $\leq .05$ \\
\hline
\end{tabular}

${ }^{1}$ Percentages indicate the proportion of the respondents who "completely agree" and "agree."

repercussions of stroke on family and social lives and the psychological reactions toward caregiving among family members caring for patients with different stroke-related impairments.

The first step in interpreting our results is to relate them to economic conditions. Luxembourg is one of the smallest European countries (502,500 inhabitants, density 190 per $\mathrm{km}^{2}$, area $2600 \mathrm{~km}^{2}$ ). Luxembourg City is a cosmopolitan capital with inhabitants of more than 170 nationalities. Braganza is the principal city of northeastern Portugal, but in this district many relatively has rural neighbourhoods (148,808 inhabitants, density 23 per $\mathrm{km}^{2}$, area $6.608 \mathrm{~km}^{2}$ ); some observations confirm this information: (a) one in four Portuguese patients was a farmer (26.1\% vs. $3.7 \%$ ); (b) the proportion of people who had never been employed was greater $(30.4 \%$ vs. 20.4\%); (c) they were older than the Luxembourg patients; (d) access to social and medical aids as well as health care may be easier in Luxembourg, a country with a high gross domestic product per inhabitant ( $\$ 105044$ vs. \$21903 for Portugal in 2009) (La Banque Mondiale, 2011), and (e) the distances Luxembourgers must travel to access the health services and facilities are short, there is geographical accessibility with a good highway network, and availability of care to the whole of the population.

Family caregivers in Luxembourg were mainly women looking after their spouses (82.3\%); most were educated beyond 12th grade and worked as employees, technicians, and intermediate professionals (49.1\%). In contrast, more Portuguese patients' daughter/son had taken over the caregiving role; family caregivers had an education level under 12th grade (76.1\%), and had never been employed (37.0\%) or a manual worker. Household impoverishment due to the costs that a disabling chronic illness entails, 
TABLE 3 The Experience of Caregiving for a Stroke-Survivor. $\%{ }^{1}$

\begin{tabular}{|c|c|c|c|c|}
\hline & & $\begin{array}{c}\text { Luxembourg } \\
\text { caregivers } \\
n=62\end{array}$ & $\begin{array}{l}\text { Portugal } \\
\text { caregivers } \\
n=46\end{array}$ & $p$ \\
\hline \multirow{7}{*}{$\begin{array}{l}\text { Caregiver's } \\
\text { esteem }\end{array}$} & I really want to care for him/her. & 88.9 & 58.7 & $\leq .01$ \\
\hline & I feel privileged to care for him/her. & 65.2 & 52.2 & .290 \\
\hline & I enjoy caring for him/her. & 75.6 & 73.9 & 1.000 \\
\hline & $\begin{array}{l}\text { Caring for him/her makes me feel } \\
\text { good. }\end{array}$ & 66.7 & 77.8 & .347 \\
\hline & Caring for him/her is important to me. & 88.9 & 65.2 & $\leq .01$ \\
\hline & $\begin{array}{l}\text { I will never be able to do enough } \\
\text { caregiving to repay him/her } \\
\text { (reversed). }\end{array}$ & 40.0 & 21.7 & .072 \\
\hline & $\begin{array}{l}\text { I resent having to care for him/her } \\
\text { (reversed). }\end{array}$ & 9.1 & 2.2 & .198 \\
\hline \multirow[t]{5}{*}{$\begin{array}{l}\text { Lack of family } \\
\text { support }\end{array}$} & $\begin{array}{l}\text { It is very difficult to get help from the } \\
\text { family in taking care of him/her. }\end{array}$ & 11.1 & 0.0 & $\leq .05$ \\
\hline & $\begin{array}{l}\text { Since caring for him/her, I feel the } \\
\text { family has abandoned me. }\end{array}$ & 6.7 & 0.0 & .117 \\
\hline & $\begin{array}{l}\text { The family (brothers. sisters. children) } \\
\text { left me alone to care for him/her. }\end{array}$ & 34.1 & 0.0 & $\leq .001$ \\
\hline & $\begin{array}{l}\text { The family works together at caring for } \\
\text { him/her (reversed). }\end{array}$ & 51.1 & 64.4 & .286 \\
\hline & $\begin{array}{l}\text { Others have dumped caring for } \\
\text { him/her onto me. }\end{array}$ & 26.1 & 0.0 & $\leq .001$ \\
\hline \multirow{3}{*}{$\begin{array}{r}\text { Impact on } \\
\text { finances }\end{array}$} & It is difficult to pay for him/her. & 6.7 & 33.3 & $\leq .01$ \\
\hline & $\begin{array}{l}\text { Financial resources are adequate } \\
\text { (reversed). }\end{array}$ & 73.9 & 32.6 & $\leq .001$ \\
\hline & $\begin{array}{l}\text { Caring for him/her puts a financial } \\
\text { strain on me. }\end{array}$ & 4.4 & 33.3 & $\leq .001$ \\
\hline \multirow[t]{5}{*}{$\begin{array}{l}\text { Impact on } \\
\text { activity }\end{array}$} & $\begin{array}{l}\text { I have to stop in the middle of my } \\
\text { work or activities to provide care. }\end{array}$ & 19.6 & 41.3 & $\leq .05$ \\
\hline & $\begin{array}{l}\text { I have eliminated things from my } \\
\text { schedule since caring for him/her. }\end{array}$ & 28.9 & 80.4 & $\leq .001$ \\
\hline & $\begin{array}{l}\text { My activities are centered on the care } \\
\text { for him/her. }\end{array}$ & 43.5 & 58.7 & .211 \\
\hline & $\begin{array}{l}\text { I visit family and friends less since I } \\
\text { have been caring for him/her. }\end{array}$ & 33.3 & 34.8 & 1.000 \\
\hline & $\begin{array}{l}\text { The constant interruptions make it } \\
\text { difficult to find time for relaxation. }\end{array}$ & 24.4 & 65.2 & $\leq .001$ \\
\hline \multirow[t]{4}{*}{$\begin{array}{l}\text { Impact on } \\
\text { health }\end{array}$} & $\begin{array}{l}\text { I feel strong enough to care for } \\
\text { him/her. }\end{array}$ & 71.1 & 31.1 & $\leq .001$ \\
\hline & $\begin{array}{l}\text { I am healthy enough to care for } \\
\text { him/her (reversed). }\end{array}$ & 80.0 & 56.5 & $\leq .05$ \\
\hline & $\begin{array}{l}\text { My health has become worse since I've } \\
\text { been caring for him/her. }\end{array}$ & 13.6 & 45.7 & $\leq .001$ \\
\hline & $\begin{array}{l}\text { Since caring for him/her, it seems like } \\
\text { I'm tired all of the time. }\end{array}$ & 35.6 & 54.3 & .093 \\
\hline
\end{tabular}

${ }^{1}$ Percentages indicate the proportion of the respondents who "completely agree" and "agree." 
TABLE 4 Stroke-Related Repercussions for the Couple by the Spouse Caregivers. \% ${ }^{1}$

\begin{tabular}{|c|c|c|c|c|}
\hline & & $\begin{array}{l}\text { Luxembourg } \\
\text { caregivers } \\
n=62\end{array}$ & $\begin{array}{c}\text { Portugal } \\
\text { caregivers } \\
n=46\end{array}$ & $p$ \\
\hline \multirow{8}{*}{$\begin{array}{l}\text { Disruptions within } \\
\text { the couple } \\
\text { relationship }\end{array}$} & $\begin{array}{l}\text { The stroke brought serious } \\
\text { upheaval to us as a couple. }\end{array}$ & 40.7 & 52.5 & .305 \\
\hline & $\begin{array}{l}\text { I have perceived the stroke as a } \\
\text { drama that my couple could not } \\
\text { overcome. }\end{array}$ & 27.8 & 35.7 & .462 \\
\hline & $\begin{array}{l}\text { The stroke has meant the end of } \\
\text { the projects for the future we } \\
\text { had as a couple. }\end{array}$ & 25.9 & 46.4 & .083 \\
\hline & $\begin{array}{l}\text { As our life as a couple was already } \\
\text { complicated, the stroke } \\
\text { worsened the situation. }\end{array}$ & 9.4 & 14.3 & .712 \\
\hline & $\begin{array}{l}\text { When a couple's relationship is } \\
\text { already conflictive, a stroke } \\
\text { worsens it. }\end{array}$ & 40.8 & 37.0 & .810 \\
\hline & $\begin{array}{l}\text { I have thought about getting } \\
\text { divorced from my spouse. }\end{array}$ & 1.9 & 14.3 & $\leq .05$ \\
\hline & $\begin{array}{l}\text { A stroke is often a cause of } \\
\text { divorce/separation. }\end{array}$ & 19.2 & 25.0 & .576 \\
\hline & $\begin{array}{l}\text { A stroke brings changes in a } \\
\text { couple's relationship. }\end{array}$ & 40.4 & 67.9 & $\leq .05$ \\
\hline \multirow[t]{3}{*}{$\begin{array}{l}\text { Impact on } \\
\text { sexuality }\end{array}$} & $\begin{array}{l}\text { It is the stroke-affected spouse } \\
\text { who refuses physical relations. }\end{array}$ & 15.2 & 29.6 & .229 \\
\hline & $\begin{array}{l}\text { In relation to sexuality, things } \\
\text { have changed for us. }\end{array}$ & 27.1 & 67.9 & $\leq .001$ \\
\hline & $\begin{array}{l}\text { Since the stroke onset, we no } \\
\text { longer have sexual relations. }\end{array}$ & 25.0 & 59.3 & $\leq .01$ \\
\hline \multirow{4}{*}{$\begin{array}{l}\text { Caregiver's feelings } \\
\text { for the } \\
\text { stroke-affected } \\
\text { spouse }\end{array}$} & $\begin{array}{l}\text { The stroke has changed my } \\
\text { spouse so much that I feel I am } \\
\text { with somebody else. }\end{array}$ & 3.8 & 14.3 & .175 \\
\hline & $\begin{array}{l}\text { The character of my } \\
\text { stroke-affected spouse has } \\
\text { completely changed, since the } \\
\text { stroke onset. }\end{array}$ & 56.5 & 60.9 & .696 \\
\hline & $\begin{array}{l}\text { When we have lived together for a } \\
\text { long time, we are more tolerant } \\
\text { with each other. }\end{array}$ & 90.6 & 96.4 & .659 \\
\hline & $\begin{array}{l}\text { My spouse's stroke has brought us } \\
\text { closer. }\end{array}$ & 61.2 & 57.1 & .811 \\
\hline
\end{tabular}

${ }^{1}$ Percentages indicate the proportion of the respondents who "completely agree" and "agree."

low educational level of family members, and pressure on the stroke patient/caregiver pair's relationship may intensify the caregiving-related burden and negatively affect the health status of both. In a context of gender unbalanced sharing of the family responsibilities, taking over the roles that the stroke-affected spouse or parent cannot carry out anymore can be viewed as increasing the caregiver's burden (Baumann, Lurbe-Puerto, Alzhaouri, \& Aiach, 2011). 
In the scientific literature concerning inequalities in health, the cumulative role of the social, economic, and cultural determinants, which influence living conditions, and the roles of preventive behavior and access to services are well documented. Therefore, it is reasonable to postulate that the effect of an event such as stroke will be greater and more serious in a family already facing disadvantages in health care and, vice versa, that the effect throughout life of health problems will be greater when the individual concerned faces social disadvantage (Braveman, 2006). Our research focuses on the main family caregivers, asking: Do they constitute a "population at risk" for our health system? What is the value of keeping patients at home if family caregivers become exhausted to the detriment of their own health? How do the experience of caregiving, the repercussions on social relationships and life satisfaction differ between families with lifestyles more reliant on family support and those with lifestyles such as observed in Luxembourg, where expectations of institutional services would be higher?

A pleasant surprise is to observe that the life satisfaction scores of caregivers in Luxembourg and northeastern Portugal were similar (7.2/10 and 6.7/10, respectively). However, compared to the corresponding national mean in 2009 in the European Quality of Life Survey (EFILWC, 2010; i.e., 7.85 and 6.25/10, respectively), the Luxembourg respondents were less satisfied with their life as a whole than the global population, whereas the opposite was true of the Portuguese interviewees. Although national means include all age groups, age had little impact on life satisfaction. Furthermore, the general pattern in Europe was that people below 35 and those above 65 are on average slightly more satisfied than those aged 35 to 64 (EFILWC, 2010). This trend may reflect higher unfulfilled expectations among caregivers in Luxembourg, most of whom are the spouses of their care-recipient-expectations of their environment (family, social networks, health professionals, and community-based resources) in taking over the basic health, social, and educational care of their care-recipients (Oupra et al., 2010). More specifically, it may highlight the lack of family support they perceive in helping stroke patients with those needs not covered by the available community services. Moreover, family care may be regarded as intrusive for the care-recipient in societies in which the welfare state is more interventionist, and its legitimacy may be questioned as it is not based on the "expertise" of a health professional or a personal care assistant (Mitnick, Leffler, \& Hood, 2010).

The stronger extended family bonds of the northeastern Portuguese caregivers, among whom there are many daughters/sons, and the ready availability of support for the care-recipient may have created a more bearable equilibrium between expectations, wishes, and the reality of caring (Leandro, Baumann, \& Felizes, 2011). People in rural southern Europe can generally count on efficient family network resources (Leandro, 2009). The stroke-related limitations and challenges they perceived concerned the 
development of their inner resources and financial constraints. In socioeconomically wealthier communities, such as Luxembourg, caregivers are less concerned about the event-related financial strain. However, wealth does not protect people from unexpected major life events like stroke. In both contexts, stroke is viewed as a painful family experience involving emotional and relational adjustments, and not just adaptation to changes in material conditions. The EQLS of 2007 and 2009 concluded that deprivation affects life satisfaction in all countries, but in those with a higher level of overall prosperity, both inequalities and thwarted plans for the future exert a stronger negative effect (EFILWC, 2009, 2010). Family endorsement and feeling surrounded by loved ones are of high value in helping to counter negative feelings related to dealing with a difficult situation.

In addition, our findings must relate to the stroke-health-related characteristics of the patients; mainly men in both countries, they were older in northeastern Portugal. At the time of the stroke event, the majority of the Luxembourg respondents were educated to the 12th grade or beyond, and the Portuguese were predominantly never employed or farmers. The life satisfaction of the Luxembourg patients was higher (7.1/10 vs. 5.7/10 in Portugal). Life satisfaction after a stroke onset has been considered as a rehabilitation outcome. In a previous study conducted by the authors with the same populations, our results observed that life satisfaction was higher among women and lower among subjects with impaired motor functions. It was lower among Portuguese respondents with low-level education and higher among those at work. In Luxembourg, retired people had more life satisfaction than did working people. Controlling for socioeconomic factors, life satisfaction was associated with feelings-Newsqol (Newcastle StrokeSpecific Quality of Life Measure) among Luxembourg residents, and with feelings-, mobility- and self-care-Newsqol among Portuguese respondents. Life satisfaction of patients was strongly related to that of family caregivers among the Portuguese respondents but the relationship was moderate in Luxembourg. The survivors' life satisfaction was not correlated with any Whoqol-bref (World Health Organization Quality of Life-bref) domain in the Luxembourg group, but was correlated with the Whoqol-bref psychological, social relationships, and environment domains among the Portuguese respondents (Baumann, Lurbe-Puerto, Leandro, \& Chau, 2012).

Social circumstances and physical characteristics can predict vulnerability to future difficulties. Depending on the lifestyle and the material life conditions they were used to, the enhancement of a caregiver's quality of life can help maintain the survivor's life satisfaction, particularly in a rural setting. This can be explained in terms of the environment and lifestyle factors: distances are short between all beneficiaries and the available health facilities and services, and from a geographical viewpoint, the structures of health care are easy accessible to the whole population. The financial and psychological instability that accompanies negative life events may reveal or 
revive latent weaknesses that otherwise would not appear and would not affect health.

More family caregivers among the northeastern Portuguese respondents reported experiencing deterioration in health due to the demands of caregiving, as observed in some previous research (Lucas, Clark, Georgellis, \& Diener, 2003; Ostwald, Godwin, \& Cron, 2009). Supporting a stroke-affected spouse or a close relative may be taken for granted as a family duty, but that does not mean it is easy (Low, Payne, \& Roderick, 1999). Given that the stroke patients surveyed in Portugal were older and had more neurological impairments, our findings are in line with Forsberg-Wärleby, Möller, and Blomstrand (2004). More northeastern Portuguese caregivers also manifested general uncertainty about interacting with their care-recipient and reported stroke patients to be socially undervalued. Portuguese family caregivers felt more compelled to interrupt their usual daily activities or cancel planned activities in order to provide care. In the same way, the increased responsibility that stroke-related residual disabilities and health care tasks create for caregivers seems to be more arduous when they perceive it as "difficult" to manage and as requiring being at the care-recipient's disposal.

Concerning the repercussions of the stroke-event for couples, the northeastern Portuguese caregivers reported a decline in their sexual life with their stroke-affected spouses. This trend has also been observed elsewhere (Carlsson, Forsberg-Warleby, Moller, \& Blomstrand, 2007) and it may also be linked to their older age and greater neurological impairment. Nearly all the main caregivers interviewed agreed with the item: "When we have lived together for a long time, we are more tolerant with each other." Mutuality in the couple, which includes the affective relationship involving shared activities, has been demonstrated to contribute to a fulfilling adjustment to the post-stroke situation (Forsberg-Wärleby et al., 2004; Korpelainen, Nieminen, \& Myllyla, 1999).

\section{LIMITATIONS OF THE RESEARCH}

Our results should be interpreted with caution for the following reasons: we surveyed small samples of volunteers who gave their consent. Effectively, 2 years post-event, more patients are dead, live in institutional settings, or in other family homes. The estimated participation rates were low, but similar to recent literature (27\%; Bergstöm, Eriksson, von Koch, \& Tham, 2011). A shortcoming of our research protocol is that we requested informed consent by a posted letter, which may have reduced the rate of response. Second, interviews took place in patients' homes, which involves intimacy and some people are known to find this difficult. Third, those who agreed to take part were likely to be concerned with health issues; motivated people 
willing to share with us their opinions and make their views broadly known. Furthermore, as our data suggested, the experience of caregiving depends on the cultural and socioeconomic life conditions in which it is carried out.

\section{PRACTICAL IMPLICATIONS}

Our research goals were in line with the recommendations adopted at the "Helsingborg Declaration on European Stroke Strategies" for 2015 (Kjellstrom, Norrving, \& Shatchkute, 2007), and more specifically, the World Health Organization (WHO)'s call for the development of primary health care systems that would provide preventive care, counseling, and socioeducational support services (WHO-Europe, 2006). By applying an approach intended to reflect the genuine concerns of individuals and populations, we sought to encourage all those involved in producing guidance and advice to take into account caregivers' actual experiences and promote stronger "patient-caregiver" pair-targeted support. The evidence-based analytical insights of this research have practical implications for social work that could be incorporated into supportive intervention, which is consistent with the recommendations adopted at the "Stroke Synergium. Stroke: Working Toward a Prioritized World Agenda" (Hachinski et al., 2010).

The processes affecting home-based care provision are dependent on the family organization of care, which is affected by the availability of health care services and community-based resources (Mold et al., 2003). Analysis of the northeastern Portuguese data highlight the fact that although effective family networks are necessary to reduce the caregiver's burden, there is also a need to provide facilities that enable caregivers to find time for relaxation and to take part in scheduled activities important for their own personal development and entertainment. Applying a "capability approach" (Hall \& Taylor, 2009; Sen, 1999), in order to adapt to the post-stroke situation, the caregiver and care-recipient pairs need community-based support to increase their ability to find the mutual equilibrium necessary for fulfilled social lives. This will reinforce their physical and mental capacity to face the challenges of caregiving. It will also help to avoid resentment and promote psychological strength and confidence in the future. This suggests that there is value in developing facilities that would not only prevent caregivers being overwhelmed by the demands of the practical care tasks, but be responsive to the need for "a space of their own."

Being asked for their life conditions and psychological reactions may give these family caregivers the room to speak to social workers about intimate matters with a bearing on how the caregiving role is conducted and experienced. This approach may provide valuable contextual information about home rehabilitation and, as it takes account of the caregiver's perspective, may foster partnership and be particularly conducive 
to family-specific interventions (von Koch, Holmqvist, Wottrich, Tham, \& de Pedro-Cuesta, 2000).

\section{REFERENCES}

Antoine, P., Quandalle, S., \& Christophe, V. (2010). Living with a chronically ill relative: Assessment of positive and negative dimensions of the experience of natural caregiver. Annales Médico-Psychologiques, 168(4), 273-282.

Baumann, M., Briançon, S., \& Deschamps, J.P. (1992). Les réseaux de soutien familiaux et la promotion de la santé. Archives of Public Health, 50, 387-395.

Baumann, M., \& Aïach, P. (2009). The main informal caregiver vis-à-vis the CVA of a relative. Medecine, 5, 184-188.

Baumann, M., Lurbe-Puerto, K., Alzahouri, K., \& Aïach, P. (2011). Increased residual disability among post-stroke survivors, and the repercussions for the lives of informal caregivers. Topics Stroke Rehabililation, 18(2), 162-171.

Baumann, M., Lurbe-Puerto, K., Leandro, M.E., \& Chau, N. (2012). Life satisfaction of two-year post-stroke survivors: Effects of socio-economic factors, motor impairment, Newcastle Stroke-Specific Quality of Life Measure and World Health Organization Quality of Life-Brief of informal caregivers in Luxembourg and a rural area in Portugal. Cerebrovascular Disease, 33, 219-230.

Bergstöm, A.L., Eriksson, G., von Koch, L., \& Tham, K. (2011). Combined life satisfaction with stroke and their caregivers: Associations with caregiver burden and the impact of stroke. Health and Quality of Life Outcomes, 11, 9-11.

Brännholm, I.B., Lundmark, P., Mansson, M., \& Fugl-Meyer, A.R. (1996). On life satisfaction in subjects with neurological disorders. NeuroRebabilitation, 2, 63-67.

Braveman, P. (2006). Health disparities and health equity: Concepts and measurement. Annual Review of Public Health, 27, 167-194.

Campbell, A. (1981). The Sense of Well-Being in America. New York, NY: McGraw Hill.

Carlsson, G.E., Forsberg-Warleby, G., Moller, A., \& Blomstrand, C. (2007). Comparison of life satisfaction within couples one year after a partner's stroke. Journal of Rehabilitation Medicine, 39(3), 219-224.

Clark, M.S., \& Smith, D.S. (1999). Changes in family functioning for stroke rehabilitation patients and their families. International Journal of Rebabilitation Research, 22(3), 171-179.

Ekstam, L., Uppgard, B., von Koch, L., \& Tham, K. (2011). Functioning in everyday life after stroke: A longitudinal study of elderly people receiving rehabilitation at home. Scandinavian Journal of Caring Sciences, 21, 434-446.

European Foundation for the Improvement of Living and Working Conditions (EFILWC). (2009). Trends in Quality of Life in the EU 2003-2009. Retrieved from www.eurofound.europa.eu

European Foundation for the Improvement of Living and Working Conditions (EFILWC). (2010). How are you? Quality of Live in Europe. Focus issue June 8, 2010. Retrieved from www.eurofound.europa.eu/publications/focusform.htm

Eurostats. (2009). Health Statistics-Atlas on Mortality in the European Union. Theme: Population and Social Conditions. Collection: Statistical books. Luxemburg: Office for Official Publications of the European Communities. 
Forsberg-Wärleby, G., Möller, A., \& Blomstrand, C.J. (2004). Life satisfaction in spouses of patients with stroke during the first year after stroke. Rehabilitation Medicine, 36(1), 4-11.

Given, B., Stommel, M., Collins, C., King, S., \& Given, C.W. (1992). Responses of elderly spouse caregivers. Research in Nursing \& Health, 13, 77-85.

Gottlieb, A., Golander, H., Bar-Tal, Y., \& Gottlieb, D. (2001). The influence of social support and perceived control on handicap and quality of life after stroke. Aging, 13(1), 11-15.

Hachinski, V., Donnan, G.A., Gorelick, P.B., Hacke, W., Cramer, S.C., Kaste, M., . . . Tuomilehto, J. (2010). Stroke Synergium. Stroke: Working toward a prioritized world agenda. Cerebrovascular Disease, 30(2), 127-147.

Hall, P., \& Taylor, R.C. (2009). Health, social relations and public policy. In P. Hall \& M. Lamont (eds.), Successful Societies: How Institutions and Culture Affect Health (pp. 82-103). Cambridge, England: Cambridge University Press.

Han, B., \& Haley, W.E. (1999). Family caregiving for patients with stroke: Review and analysis. Stroke, 30, 1478-1485.

Kelly-Hayes, P.M., Robertson, J.T., Broderick, J.P., Duncan, P.W., Hershey, L.A., Roth, E.J., Thies, W.H., \& Trombly, C.A. (1998). The American Heart Association stroke outcome classification. Stroke, 29, 1274-1280.

Kjellstrom, T., Norrving, B., \& Shatchkute, A. (2007). Helsingborg Declaration 2006 on European stroke strategies. Cerebrovascular Disease, 23(2-3), 231-241.

von Koch, L., Holmqvist, L.W., Wottrich, A.W., Tham, K., \& de Pedro-Cuesta, J. (2000). Rehabilitation at home after stroke: A descriptive study of an individualized intervention. Clinical Rehabilitation, 14(6), 574-583.

Korpelainen, J.T., Nieminen, P., \& Myllyla, V.V. (1999). Sexual functioning among stroke patients and their spouses. Stroke, 30, 715-719.

La Banque Mondiale. (2011). PIB par habitant. Retrieved from http://donnees. banquemondiale.org/indicateur/NY.GDP.PCAP.CD

Leandro, M.E. (coord.) (2009). Saúde e Sociedade. Os contributos (in)visiveis da família. Psicosoma (Ed.). (p. 510). Viseu, Portugal.

Leandro, M.E., Baumann, M., \& Felizes, J. (2011). Construçao de rupturas sociais: pobreza e exclusao social na perspectiva das sociologias da integracao social. In M.E. Leandro (coord.), Laços Familiares e Sociais (pp. 227-248). Ed. Psicosoma, coll. Familia, Viseu, Portugal.

Low, J.T.S., Payne, S., \& Roderick, P. (1999). The impact of stroke on informal carers: A literature review. Social Science \& Medicine, 49(6), 711-725.

Lucas, R.E., Clark, A.E., Georgellis, Y., \& Diener, E. (2003). Reexamining adaptation and the set point model of happiness: Reactions to changes in marital status. Journal of Personal \& Social Psychology, 84(3), 527-539.

Miller, T.W. (1989). Stressful Life Events. Madison, WI: International Universities Press.

Mitnick, S., Leffler, C., \& Hood, V. (2010). Family caregivers, patients and physicians: Ethical guidance to optimize relationships. Journal of General \& Internal Medicine, 25(3), 255-260.

Mold, F., McKevitt, C., \& Wolfe, C. (2003). A review and commentary of the social factors which influence stroke care: Issues of inequalities in qualitative literature. Health E Social Care in the Community, 11(5), 405-414. 
Musschenga, A.W. (1997). The relation between concepts of quality-of-life, health and happiness. Journal of Medicine E Philosophy, 22(1), 11-28.

Nijboer, C., Triemstra, M., Tempelaar, R., Sandermanc, R., \& Van Den Bosa, G.A.M. (1999). Measuring both negative and positive reactions to giving care to cancer patients: Psychometric qualities of the Caregiver Reaction Assessment (CRA). Social Science \& Medicine, 48, 1259-1269.

National Stroke Association (2007). Hope: The stroke recovery guide. Denver, CO: The National Stroke Association.

OMS Europe. (2004). Panorama de la Santé au Luxemburg. Copenhagen, Denmark: Office for Official Publications of the European Communities.

Ostwald, S.K., Godwin, K.M., \& Cron, S.G. (2009). Predictors of life satisfaction in stroke survivors and spousal caregivers twelve to twenty-four months post discharge from inpatient rehabilitation. Rehabilitation Nursing, 34(4), 160-174.

Oupra, R., Griffiths, R., Pryor, J., \& Mott, S. (2010). Effectiveness of supportive educative learning programme on the level of strain experienced by caregivers of stroke patients in Thailand. Health \& Social Care in the Community, 18(1), 10-20.

Parker, G., Corden, A., \& Heaton, J. (2011). Experiences of and influences on continuity of care for service users and carers: Synthesis of evidence from a research programme. Health \& Social Care in the Community, 19(6), 576-601.

Poulshock, S.W., \& Deimling, G.T. (1984). Families caring for elders in residence: Issues in the measurement of burden. Journal of Gerontology, 39, 230-239.

Rosamond, W., Flegal, K., Friday, G., Furie, K., Go, A., Greenlund, K., Haase, N., Ho, M., Howard, V., Kissela, B., Kittner, S., Lloyd-Jones, D., McDermott, M., Meigs, J., Moy, C., Nichol, G., O’Donnell, C.J., Roger, V., Rumsfeld, J., Sorlie, P., Steinberger, J., Thom, T., Wasserthiel-Smoller, S., \& Hong, Y. (2007). Heart disease and stroke statistics 2007 update: A report from the American Heart Association statistics committee and stroke statistics subcommittee. Circulation, 115, 69-171.

Salisbury, L., Wilkie, K., Bulley, C., \& Shiels, J. (2011). "After the stroke": Patient's and carers' experiences of healthcare after stroke in Scotland. Health \& Social Care in the Community, 18(4), 424-432.

Sen, A.K. (1999). Development as freedom. New York, NY: Knopf.

Tsouna-Hadjis, E., Vemmos, K.N., Zakopoulos, N., \& Stamatelopoulos, S. (2000). First-stroke process: The role of family social support. Archives of Physical Rehabilitation, 81, 881-887.

Veenhoven, R. (2000). The four qualities of life. Journal Happiness Studies, 1(1), $1-39$.

Vitanen, M., Fugl-Meyer, K.S., Bernspang, B., \& Fugl-Meyer, A.R. (1988). Life satisfaction in long-term survivors after stroke. Scandinavian Journal of Rebabilitation Medicine, 20(1), 17-24.

Wiles, J. (2003). Informal caregivers' experiences of formal support in a changing context. Health \& Social Care in the Community, 11(3), 189-207.

Wolfe, C.D.A. (2000). The impact of stroke. British Medical Bulletin, 56(2), 275-286.

World Health Organization Regional Office for Europe. (2006). Helsingborg Declaration on European Stroke Strategies, T. Kjellstrom, B. Norrving, A. Shatchkute (eds.), WHO Regional Office for Europe Publications. Retrieved from http://www.acponline.org/isim/stroke.pdf 